\title{
High incidence of infection of an undescribed microsporidium (Microspora) in the communal bee Andrena scotica (Hymenoptera, Andrenidae)
}

\author{
RJ Paxton ${ }^{*}$, I Fries $^{2}$, NJ Pieniazek ${ }^{3}$, J Tengö $^{4}$ \\ ${ }^{I}$ Lehrstuhl Entwicklungsphysiologie, Zoologisches Institut der Universität Tübingen, \\ Auf der Morgenstelle 28, D-720 76 Tübingen, Germany; \\ ${ }^{2}$ Department of Entomology, Swedish University of Agricultural Sciences, Box 7044, \\ S-750 07 Uppsala, Sweden; \\ ${ }^{3}$ Division of Parasitic Diseases, Centers for Disease Control and Prevention, \\ 4770 Buford Highway NE, Mailstop F13, Atlanta, GA 30341, USA; \\ ${ }^{4}$ Ecological Research Station of Uppsala University, Ölands Skogsby 6280, \\ S-38693 Färjestaden, Sweden
}

(Received 7 March 1997; accepted 25 June 1997)

\begin{abstract}
Summary - We document the abundance and distribution of the spores of an undescribed species of microsporidium within its host, the communal bee Andrena scotica, and relationships between this parasite and its host. Only the host's adipose tissue (fat bodies) appeared infected, with up to $118 \times$ $10^{6}$ spores per bee. All hosts at one field site were infected. High spore load within hosts appeared to curtail female reproductive activity. However, we were unable to discern the microsporidium's effects on male fecundity in that some males with a high spore load did undertake mate searching activity. Longevities of naturally infected $A$ scotica males and females in a flight cage were apparently unaffected by the microsporidium. Spores were found in A scotica from other field sites but not in other species of bees, suggesting the microsporidium has a high degree of host specificity.
\end{abstract}

Andrena scotica / communal bee / infection / Microspora / microsporidium

\section{INTRODUCTION}

Microspora is a large group of obligate intracellular parasites that appear to affect all major animal groups. They are particularly widespread and abundant in arthropods, though for many their host specificity is little known. Their effects on hosts vary from the benign to highly pathogenic, and they may have significant effects on the population dynamics of their hosts (Briano et al, 1995).

* Correspondence and reprints

Tel: (49) 7071-2975342; fax: (49) 7071-296950; e-mail: robert.paxton@uni-tuebingen.de 
Notwithstanding their apparent prevalence in arthropods, only three species of microsporidia are currently known from the over 20000 described species of bees (Apoidea) (Michener, 1974). Nosema apis and Nosema ceranae are parasites of the ventricular epithelial cells of Apis mellifera and Apis cerana, respectively (Fries et al, 1996). The former can have a severely debilitating effect upon its host in temperate climates (Fries, 1993). Nosema bombi, originally confused with $N$ apis (eg, Showers et al, 1967, but see Eijnde and Vette, 1993; McIvor and Malone, 1995), is an infection of apparently numerous species of Bombus across the world (MacFarlane et al, 1995). It parasitises cells of host Malpighian tubules, and possibly other tissue types too (Eijinde and Vette, 1993), though its effects on its hosts are seemingly benign (Fisher and Pomeroy, 1989). In a recent study of European bumble bees, Shykoff and SchmidHempel (1991b) found a low prevalence of $N$ bombi. However there is in general little data on the abundance and distribution of microsporidian parasites in natural populations of hosts, or on their effects on hosts.

In this paper we report on a high incidence of the spores of a currently undescribed microsporidium within the haemocoel of imagines of a primitively social (communal) bee Andrena scotica Perkins 1916 (= Andrena jacobi Perkins 1921) in SE Sweden. We document the distribution and abundance of these microsporidian spores within and among hosts and some relationships between host and microsporidium. A full description of the microsporidium will be given by Fries et al in a future paper.

\section{MATERIALS AND METHODS}

\section{The host, Andrena scotica}

The host, A scotica, is a fossorial bee, common and widespread in northern Europe (Westrich,
1989). It is univoltine, imagines flying from May to early July at our principal study site, Törnbottens Stugby, on the Baltic island of Öland, SE Sweden ( $16^{\circ} 34^{\prime}$ E, $56^{\circ} 29^{\prime} \mathrm{N}, 35 \mathrm{~m}$ asl). At this site, all nests of $A$ scotica have been permanently marked with plastic and metal tags. Adult female bees are communal, that is, two or more, and rarely up to several hundred, females share a common nest entrance (Paxton et al, 1996). Beneath the nest entrance, each female constructs her own brood cells in the soil, mass provisions them with pollen and nectar, and in each she lays one egg. Larvae consume the stored food and then metamorphose into adults before entering winter diapause in their natal cells (Paxton et al, 1997). Offspring emerge above ground in the following spring through their mother's nest entrance; sons remain above ground in search of mates whilst mated daughters construct and provision their own cells in fossorial nests. Imagines that emerge and fly in one year do not survive to the following year.

\section{Collection of material from the host bee, $A$ scotica}

A random sample of host males and females was collected from Törnbottens Stugby in 1995 as they first emerged in May and June from their natal nests (for details, see Paxton and Tengö, 1996). These 'emerging' A scotica were weighed on an electronic benchtop balance to $\pm 0.1 \mathrm{mg}$ to provide an estimate of their size (Rust, 1991).

Additional, reproductively active males were collected at random from Törnbottens Stugby in 1995 as they undertook their characteristic mate searching flights (Tengö, 1979) over bushes and low trees (2-10 m height), and additional, reproductively active females were collected at random in the same year as they returned to nests at Törnbottens Stugby with pollen provisions. The head widths of these imagines, termed 'field' bees, were measured under a dissection microscope using an eyepiece graticule to $\pm 0.03 \mathrm{~mm}(16 \times$ magnification) in lieu of weight as an estimate of body size because weights of field bees vary considerably depending upon the quantity of nectar and pollen that they carry.

'Overwintering' adults were excavated from their underground natal cells at Törnbottens Stugby in the winter of 1995-96 and their head widths were also measured. 
Adipose tissue (fat bodies), brain, Dufour's gland, Malpighian tubules, ovarioles, small intestine, thoracic muscle and the ventriculus of infected imagine hosts were carefully examined using phase contrast light microscopy $(400 \times$ magnification) to locate microsporidian spores. Spores were removed from host tissue, fixed and stained for transmission electron microscopy to aid in identification (Fries et al, unpublished data).

To determine the incidence of infection of 'emerging' host bees at Törnbottens Stugby, imagines were dissected under insect saline $(0.9 \%$ $\mathrm{NaCl}$ ) and scored for the presence or apparent absence of microsporidian spores in their adipose tissue. For other 'emerging' hosts, and all 'field' and 'overwintering' bees collected from Törnbottens Stugby, we quantified the number of spores per bee by homogenising imagines in 1 or $10 \mathrm{~mL}$ of insect saline and counting microsporidian spores in the homogenate using a Neubauer Improved haemocytometer (depth $0.1 \mathrm{~mm}$, see Cantwell, 1970).

\section{Longevity of infected host bees}

To document the relationship between the abundance of the microsporidium in a host and host longevity, A scotica imagines were collected as they emerged from their natal nests at Törnbottens Stugby in 1995, weighed and individually marked on their thoraxes. Then they were held in a nylon netting flight cage $(1 \mathrm{~m} \times 1 \mathrm{~m} \times 1 \mathrm{~m})$ in a room illuminated by daylight and with an ad libitum supply of honey solution and water. Upon death, the date was recorded and immediately the number of microsporidian spores in the individual 'cage' bee was quantified as described above.

\section{Microsporidian spores in $\boldsymbol{A}$ scotica at other sites and in other species of bees}

To ascertain whether the microsporidium was specific to A scotica at Törnbottens Stugby, the species was sampled from three additional sites. In 1995, A scotica individuals were collected from flowers at Abbantorp and Tävelsrum, $12 \mathrm{~km}$ north and $3 \mathrm{~km}$ south-west of Törnbottens Stugby, respectively, and both on the island of Öland, the former site probably well beyond the typical flight range of $A$ scotica. These bees were carefully examined for the presence of microsporidian spores. In 1996, A scotica female 'field' bees were also collected from flowers at Kalmar on the Swedish mainland, $14 \mathrm{~km}$ west of Törnbottens Stugby. Fat bodies of some of these bees were carefully examined for microsporidia whilst other Kalmar 'field' bees were homogenised to quantify the numbers of microsporidian spores they contained, as described above.

A small number of bees of other Andrena species was collected from Törnbottens Stugby and Kalmar in 1996 and examined for microsporidian spores. In addition, imagines of a cleptoparasitic bee, Nomada marshamella (Kirby, 1802) (Hymenoptera, Anthophoridae), whose larvae consume the offspring egg or young larva in an A scotica cell and then consume the food stores of that cell, were collected as they first emerged in spring 1995 from the natal nests of their host $A$ scotica at Törnbottens Stugby. They were also carefully examined for the presence of microsporidian spores.

\section{Statistical analysis}

A log-linear model (logit analysis, Norusis, 1990) was used to compare (i) differences among host sex, (ii) differences among host nest of origin, and (iii) the interaction between host sex and nest of origin in the proportions of $A$ scotica emerging with or apparently without spores in 1995 at Törnbottens Stugby. The relationship of host size at emergence (ordinate) upon date of emergence (abscissa) was analysed by linear regression, and differences among bees with or apparently without spores in (i) their weight at emergence and (ii) their date of emergence were tested by ANOVA.

Data on the number of spores per individual $A$ scotica were square root transformed to conform to the assumptions of ANOVA. Then ANOVA was used to compare variation in the mean number of spores per individual bee at different periods in adult life (at 'emergence', from the 'field' (site Törnbottens Stugby) when reproductively active, at death within a flight 'cage', 'overwintering', and from the 'field' [site Kalmar] when reproductively active) for both males and females. Where there was significant heterogeneity amongst groups, means were compared a posteriori using Fisher's protected least significant difference. 


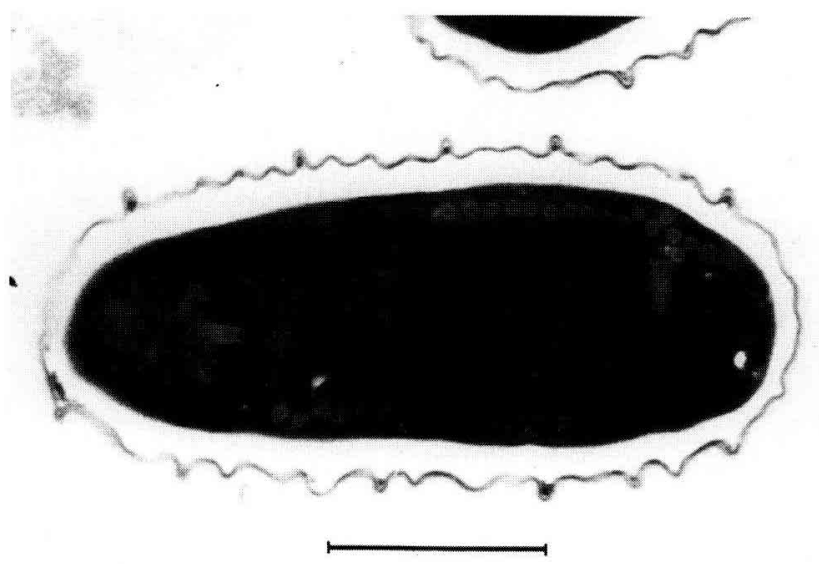

Fig 1. Transmission electron micrograph of a thin section of a microsporidian spore from the adipose tissue of a female Andrena scotica imago showing coils of the polar filament, typical of microsporidian spores. TEMfixed spores averaged $5.0 \mu \mathrm{m}$ $\times 1.8 \mu \mathrm{m}(n=14)$, and the scale bar represents $1.5 \mu \mathrm{m}$. Details of specimen preparation in Fries et al (in prep).

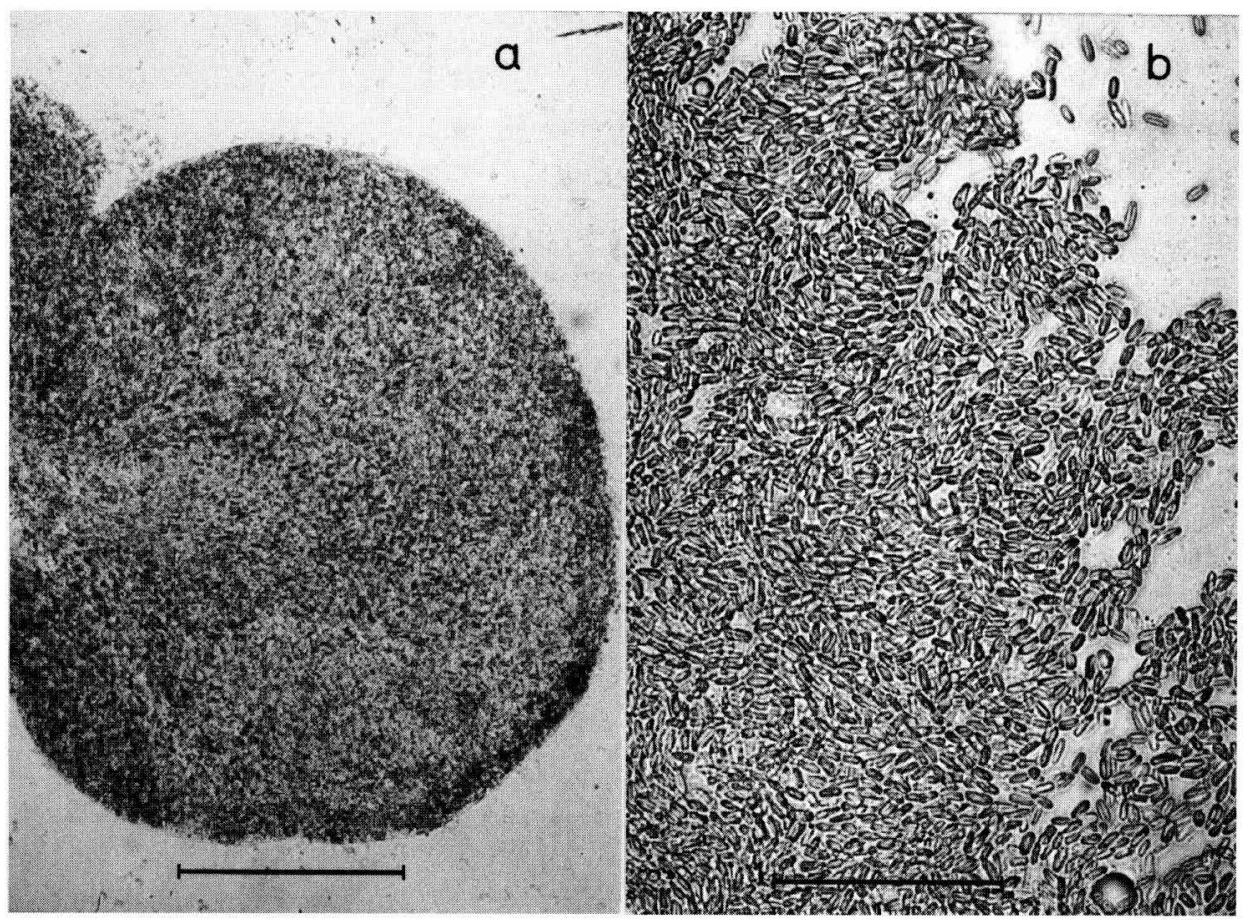

Fig 2. Light micrograph of microsporidian spores enclosed within the adipose tissue of a female Andrena scotica imago (a) and in detail (b). Fresh spores average $6.8 \mu \mathrm{m} \times 2.7 \mu \mathrm{m}(n=59)$, and the scale bars represent (a) $200 \mu \mathrm{m}$ and (b) $50 \mu \mathrm{m}$. Specimen preparation involved the squashing of freshly dissected adipose tissue in insect saline. 
Linear regression was used to examine the relationship of the number of spores per imago host (ordinate) upon the size of the host (abscissa), measured as weight or head width, for bees in each period of their adult life. Spearman rank correlation was used to investigate the relationship between imago longevity in a flight cage and number of spores at death. Statistical analyses were performed with the computer packages SPSS (Norusis, 1990) and STATVIEW (Abacus Concepts, 1995).

\section{RESULTS}

Transmission electron microscopic investigation of infected $A$ scotica tissue revealed spores with an internal anatomy comprising a complex cell wall and a coiled polar filament typical of microsporidian spores (Larsson, 1986, fig 1). Their unique exospore structure and molecular characteristics indicate that they represent a new species (Fries et al, unpublished data). All spores found in infected A scotica and reported here were of a similar size and shape, suggesting they belonged to the same species of microsporidium.

\section{Location of microsporidian spores within an imago $A$ scotica}

Microsporidian spores were primarily located within the adipose tissue of the gasters of both male and female $A$ scotica imagines. Where infection was particularly heavy, the normally pearly white fat bodies that cover the terga and sterna of the host bee appeared grey and became amorphous masses, basically sacs of microsporidian spores (fig 2) that were often ruptured, filling the haemocoel with spores. In such hosts, spores could also be found in the haemolymph of the head and mesosoma, presumably having been transported there from the haemocoel in haemolymph.

Spores of the microsporidium were not detected in other tissue of the host bee such as brain, Dufour's gland, Malpighian tubules, ovarioles, small intestine, thoracic muscle and ventriculus despite careful inspection. However, this does not preclude the existence of vegetative stages of the microsporidium in one or more of these tissue types.

\section{Prevalence of microsporidian spores in $A$ scotica}

There was a high incidence of infection of $A$ scotica by the microsporidium. Of the 87 male and 56 female $A$ scotica that were collected at first emergence from their natal nests at Törnbottens Stugby in 1995 (six nests with $n \geq 10$ bees examined) and whose fat bodies were examined by dissection and light microscopy, $87.4 \%$ clearly contained numerous microsporidian spores (table I), there being no difference between the appar-

Table I. The percentage of Andrena scotica male and female imagines collected at first emergence from six nests (those from which $n \geq 10$ bees sampled) at Törnbottens Stugby in 1995 and classified by dissection and light microscopic inspection as either containing or apparently not containing microsporidian spores. Males and females were equally likely to have been infected, but bees emerging from some nests were more heavily infected than those emerging from other nests (logit analysis, see text). The sample size, $n$, of bees examined is given in parentheses.

\begin{tabular}{lccc}
\hline \multirow{2}{*}{ Nest } & \multicolumn{3}{c}{$\begin{array}{c}\text { Percentage of A scotica } \\
\text { adults apparently infected }\end{array}$} \\
\cline { 2 - 4 } & Males & Females & Both sexes \\
\hline $\mathrm{z}$ & $93(n=14)$ & $86(n=7)$ & $90(n=21)$ \\
$\mathrm{s} 4$ & $83(n=6)$ & $75(n=4)$ & $80(n=10)$ \\
$\mathrm{s} 7$ & $100(n=15)$ & $91(n=11)$ & $96(n=26)$ \\
$\mathrm{s} 15$ & $50(n=8)$ & $50(n=4)$ & $50(n=12)$ \\
$\mathrm{s} 16$ & $80(n=15)$ & $100(n=6)$ & $86(n=21)$ \\
s30 & $93(n=29)$ & $92(n=24)$ & $92(n=53)$ \\
Total & $87(n=87)$ & $88(n=56)$ & $87(n=143)$
\end{tabular}


ent incidence of infection of male and female host bees $(G=0.062, d f=1, n s)$. There was significant variation across nests in the proportion of bees that emerged apparently containing spores $(G=14.387, d f=5$, $P<0.05)$, internest variation that was consistent across both males and females (3way interaction $G=4.330, d f=5, n s)$. However, infected bees emerged from every nest (table I). Therefore the microsporidium seems to have been widely distributed within its host population at Törnbottens Stugby.

A scotica is sexually size dimorphic; imago males are only $40 \%$ the size (weight) of females (Paxton and Tengö, 1996). Therefore males and females are henceforth analysed separately.

Weights of males or females at emergence did not vary significantly across the period of sampling at Törnbottens Stugby (ANOVA of regression: males, $\mathrm{F}=1.733$, $d f=1$ and $109, n s ;$ females, $\mathrm{F}=2.548, d f=1$ and $67, n s)$, a pattern approximately supported by analogous data from the previous spring. Further, for either sex, there was no relationship between the weight of emerging adults and whether they did or apparently did not contain spores (ANOVA: males,
$\mathrm{F}=1.334, d f=1$ and $109, n s ;$ females, $\mathrm{F}=0.231, d f=1$ and $67, n s)$. Hence infected adults of either sex were no heavier than apparently uninfected ones at emergence (table II), and they could not be distinguished visually from apparently uninfected hosts in external morphology nor in behaviour.

For male bees, there was no difference in the date of emergence of those with or apparently without spores (ANOVA $\mathbf{F}=2.110, d f=1$ and $109, n s)$. For females, however, infected hosts emerged significantly earlier than apparently uninfected ones (ANOVA $\mathbf{F}=8.301, d f=1$ and 67 , $P<0.01)$ but only by an average of 5 days (table II).

\section{Exact counts of microsporidian spores in A scotica}

Microsporidian spores were found in all bees at Törnbottens Stugby ( $n=39$ male $A$ scotica and $n=41$ female $A$ scotica, table III) that were homogenised for quantification of the number of spores per bee. Though approximately $12 \%$ of emerging $A$

Table II. Weight at emergence (in $\mathrm{mg}$ ) and date of emergence (in Julian days, where day $155=4$ th June) for male and female Andrena scotica emerging from nests at Törnbottens Stugby during 1995 and classified by dissection and light microscopic inspection as either containing or apparently not containing microsporidian spores. Within a sex, there was no difference in weight at emergence for infected versus uninfected bees (ANOVA, see text). For males, incidence of infection was not related to date of emergence, but infected females emerged earlier than apparently uninfected females (ANOVA, see text). Means are presented $\pm \mathrm{SE}$ (sample size, $n$, in parentheses).

\begin{tabular}{|c|c|c|c|c|}
\hline & \multicolumn{2}{|c|}{ Male A scotica } & \multicolumn{2}{|c|}{ Female A scotica } \\
\hline & Weight in $m g$ & Julian date & Weight in $m g$ & Julian date \\
\hline Infected bees & $\begin{array}{c}29.1 \pm 0.5 \\
(n=99)\end{array}$ & $\begin{array}{c}155.9 \pm 0.5 \\
(n=99)\end{array}$ & $\begin{array}{c}70.9 \pm 1.3 \\
(n=60)\end{array}$ & $\begin{array}{c}155.6^{a} \pm 0.6 \\
(n=60)\end{array}$ \\
\hline $\begin{array}{l}\text { Apparently } \\
\text { uninfected bees }\end{array}$ & $\begin{array}{c}27.5 \pm 1.2 \\
(n=12)\end{array}$ & $\begin{array}{c}153.8 \pm 0.9 \\
(n=12)\end{array}$ & $\begin{array}{c}69.1 \pm 5.1 \\
(n=9)\end{array}$ & $\begin{array}{c}160.4^{\mathrm{b}} \pm 1.5 \\
(n=9)\end{array}$ \\
\hline
\end{tabular}

Different letters following pairs of means within a column signify significant differences at $P<0.05$ (ANOVA). 
Table III. The number of microsporidian spores $\left(\times 10^{6}\right) \pm$ SE per Andrena scotica imago for those bees sampled from Törnbottens Stugby (TS) or Kalmar at different periods in their adult life and homogenised. For female 'field' bees and all 'overwintering' bees, counts were made on homogenates of gasters alone. Means for males are not significantly different whilst those for females are, with reproductively active females containing fewer spores than females sampled at other periods of their lives (ANOVA, see text). Sample sizes $(n)=10$ for all means except for 'cage' bees, where $n=9$ males and $n=11$ females, and 'field' bees from Kalmar, where $n=27$ females.

\begin{tabular}{llcc}
\hline $\begin{array}{l}\text { Period in imago life } \\
\text { (Site of collection) }\end{array}$ & & \multicolumn{2}{c}{ Number of microsporidian spores $\left(\times 10^{6}\right)$} \\
\cline { 3 - 4 } & & Male A scotica & Female A scotica \\
\hline At 'emergence' & mean & $17.54 \pm 4.47$ & $26.57^{\mathrm{a}} \pm 5.86$ \\
in 1995 (TS) & (range) & $(1.68-42.24)$ & $(0.56-50.88)$ \\
Active in the 'field' & mean & $17.42 \pm 5.05$ & $1.95^{\mathrm{b}} \pm 0.91$ \\
in 1995 (TS) & (range) & $(0.88-42.80)$ & $(0.02-8.40)$ \\
At death in flight & mean & $14.46 \pm 3.59$ & $37.00^{\circ} \pm 9.90$ \\
'cage' in 1995 (TS) & (range) & $(0.08-34.64)$ & $(1.60-117.92)$ \\
'Overwintering' & mean & $25.95 \pm 3.13$ & $38.233^{\mathrm{a}} \pm 7.92$ \\
in 1995/1996 (TS) & (range) & $(7.20-40.08)$ & $(6.32-74.08)$ \\
Active in the 'field' & mean & & $1.84^{\mathrm{b}} \pm 0.66$ \\
in 1996 (Kalmar) & (range) & & $(0-17.52)$ \\
\hline
\end{tabular}

Means followed by the same letter within a column are not significantly different (Fisher's protected least significant difference, $P<0.05$ ).

scotica apparently did not contain spores on visual inspection of squashed tissue, the more thorough observations provided by homogenisation of hosts suggest that every A scotica imago emerging at Törnbottens Stugby in 1995 contained some spores.

Between $16 \times 10^{3}$ and $118 \times 10^{6}$ spores were found per bee (table III). There was no difference in the number of spores per bee for A scotica males collected at the four periods in the imago's life (ANOVA F = $1.414, d f=3$ and $35, n s$, table III).

For A scotica females, in contrast, there was heterogeneity in the number of spores they contained at different periods in their adult life (ANOVA F $=27.031, d f=4$ and $63, P<0.001$, table III). Reproductively active 'field' bees contained far fewer spores than those at other periods of adult life, namely at 'emergence' or held from emergence to death in a flight 'cage' or 'overwintering' (table III).

\section{The relationship between $\boldsymbol{A}$ scotica size and the number of spores they contain}

Within any one group of male or female bees collected at a different period of imago life, there was little or no relationship between host size and the number of microsporidian spores they contained; regression analyses of the number of spores per bee upon host size were universally nonsignificant $(P>0.05$, except for 'cage' females, see below). 


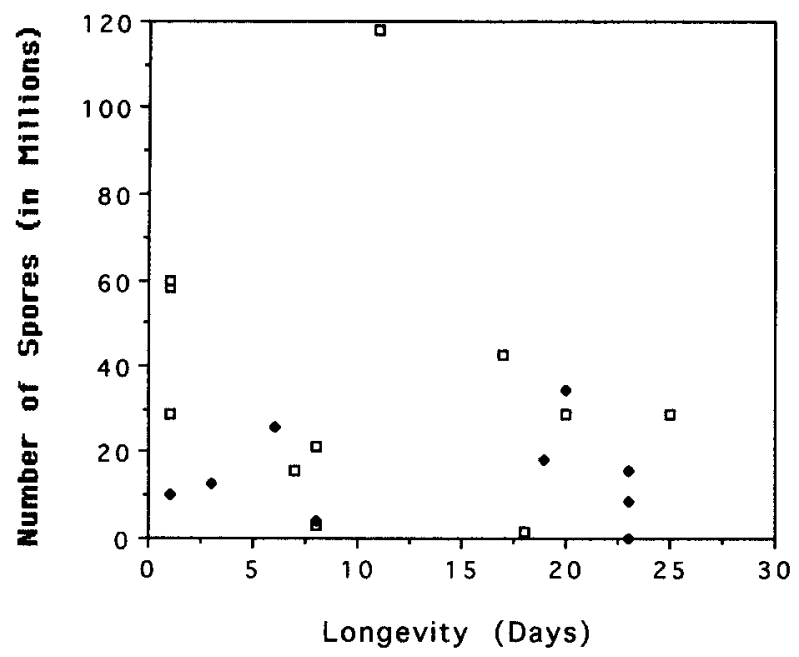

Fig 3. The number of microsporidian spores $\left(\times 10^{6}\right)$ per Andrena scotica host at imago death is plotted upon its longevity (in days) in a flight cage. Neither male nor female longevity was significantly related to their spore load (Spearman rank correlation, see text). Open squares: females; solid diamonds: males.

\section{Longevity of infected $A$ scotica in a flight cage}

For $A$ scotica adults that were held in a flight cage immediately after emergence in 1995 , there was no relationship among either males or females between longevity and numbers of microsporidian spores they contained at death (Spearman rank correlation: males, $\mathrm{r}_{\mathrm{s}}=-0.235, n=9$, $n s$; females, $\mathrm{r}_{\mathrm{s}}=$ $-0.198, n=11, n s$, fig 3).

For female $A$ scotica held in the flight cage, there was a significant positive relationship of the number of spores per host at host death upon host size (weight at emergence; ANOVA of regression, $\mathrm{F}=8.741$, $d f=1$ and $9, P<0.05$ ). However, female host longevity in the flight cage was still independent of the number of microsporidian spores it contained after partitioning out the effect of host size (Spearman rank correlation of female host longevity in the cage versus residuals from the regression of the numbers of spores per female host upon host size: $\left.\mathrm{r}_{\mathrm{s}}=-0.239, n=11, n s\right)$.

The occurrence of microsporidian spores at other field sites and in other species of bees

A high incidence of spores of the microsporidium was detected in A scotica imagines from sites other than Törnbottens Stugby, both on the island of Öland and on the nearby Swedish mainland (table IV). Indeed, the absolute number of spores in $A$ scotica 'field' bees at Kalmar was no different to that of 'field' bees collected at Törnbottens Stugby (table III). Microsporidian spores were neither detected in other species of Andrena collected from Törnbottens Stugby and Kalmar nor were they detected in $N$ marshamella at Törnbottens Stugby, the common cleptoparasite of $A$ scotica at this site (table IV). 
Table IV. Distribution of infection by microsporidian spores in Andrena scotica, other Andrena species and the cleptoparasite of $A$ scotica, Nomada marshamella, from sites in SE Sweden (TS = Törnbottens Stugby). Imagines were collected at emergence ( $N$ marshamella) or in flight from the field (all other bees) and their gastral tissues were scored for presence or apparent absence of spores by phase contrast microscopy.

\begin{tabular}{llccc}
\hline Bee species & Sex & $\begin{array}{c}\text { Site of } \\
\text { collection }\end{array}$ & \multicolumn{2}{c}{ Number of bees } \\
\cline { 4 - 5 } & & & Anfected & Not infected \\
\hline A scotica & male & Abbantorp & 3 & 0 \\
A scotica & female & Abbantorp & 1 & 5 \\
A scotica & female & Tävelsrum & 1 & 3 \\
A scotica & female & Kalmar & 14 & 1 \\
Andrena haemorrhoa $(\mathrm{F})$ & female & TS & 0 & 1 \\
Andrena nigroaenea $($ Kirby 1802$)$ & female & Kalmar & 0 & 1 \\
Andrena tibialis (Kirby 1802) & female & Kalmar & 0 & 5 \\
$N$ marshamella & male & TS & 0 & 10 \\
N marshamella & female & TS & 0 & 10 \\
\hline
\end{tabular}

\section{DISCUSSION}

\section{Distribution and abundance of microsporidan spores within and among hosts}

Fat bodies are a common site of infection of microsporidian parasites of arthropods (Raina et al, 1995). For A scotica too, the fat body appeared to be the only tissue type that was infected with microsporidia, although heavily infected hosts also contained large numbers of spores in their haemocoels, suspended in haemolymph.

Relationships between $A$ scotica size and microsporidian spore load were either weak or non-existent. Where a positive relationship did exist, namely between the number of spores and the size of female 'cage' bees, there was over a 70-fold range in the number of spores per bee for a 1.4 fold range in the size of the host. Variation in the level of infection of a host cannot be accounted for by the size of the host alone.
The microsporidium was clearly widespread among its host, A scotica, at several sites in SE Sweden, and it occurred in all imagines of both sexes at Törnbottens Stugby when examined carefully. Therefore it can potentially exert a great effect on the population dynamics of A scotica. We could not, however, detect the microsporidium in other bee species, including the host's common cleptoparasitic bee, $N$ marshamella. Parasites and parasitoids of other hymenopteran species are known to become infected with their hosts' microsporidia (Blunck, 1954; Briano et al, 1996) and may potentially act as conduits for the horizontal transfer of parasites among host species (Werren et al, 1995). That $N$ marshamella did not apparently contain microsporidian spores, though most likely ingesting the microsporidium when it consumed either its host A scotica's egg, larva or food provisions at Törnbottens Stugby, suggests a high degree of host specificity by the microsporidium. 


\section{Costs of microsporidian infection to A scotica}

Some microsporidia are pathogenic and have been associated with profound changes in host behaviour and physiology that are detrimental to host fitness or even cause host death (eg, Raina et al, 1995) whilst others have a chronic or benign effect on their host (eg, Fisher and Pomeroy, 1989). Using naturally infected hosts, results from our cage experiment suggest that $A$ scotica's microsporidium had no apparent effect on its host's longevity in the laboratory. However, natural variation among hosts in their susceptibility or tolerance to the microsporidium was not controlled; experimental manipulation of spore load would be needed to demonstrate whether or not the microsporidium reduces host longevity.

The effects of the microsporidium on male $A$ scotica reproductive activity were not immediately obvious; the number of spores of some mate searching 'field' males was no different from that of males sampled before or at emergence. This is surprising given that up to $42 \times 10^{6}$ spores were found per male, and that a male's adipose tissue may appear to have been completely exhausted owing to infection. Sperm complements of males may have been affected by the microsporidium, though they were not measured.

For female A scotica, reproductively active individuals ('field' bees) contained fewer spores than those sampled before or at emergence, suggesting that females emerging with a high spore load did not provision a nest. Thus high spore load may exert a cost to females through reduced fecundity. In other female arthropods, high rates of microsporidian infection of adipose tissue have been associated with loss of fecundity due to oocyte resorption (Raina et al, 1995).

It is more difficult to interpret the costs, if any, of the earlier emergence of $A$ scotica females whose adipose tissue was obviously infected with spores. Earlier emergence of infected A scotia females may correspond to the faster physiological ageing observed in honey bees ( $A$ mellifera) infected by $N$ apis (Wang and Moeller, 1970). Studies incorporating the experimental manipulation of levels of infection need to be undertaken in tandem with our correlational observations to evaluate more fully the costs of microsporidian infection to A scotica.

\section{Biology and mode of transmission of the microsporidium}

That the level of microsporidian infection did not vary for male $A$ scotica sampled across adult life from metamorphosis to reproductive activity in the field implies that, once spores develop within a male host larva or pupa, they remain within its adipose tissue without further multiplication. Within individual $A$ scotica females, it seems that microsporidian spores follow similar dynamics to those in male hosts, building up to variable and sometimes high numbers in overwintering adults but not increasing thereafter.

Infection of hosts thus seems to occur at the egg or larval stage, and is seemingly highly efficient, all hosts at Törnbottens Stugby being infected. Transovarial transmission, a common vertical mode of transmission, is frequent in many invertebrate microsporidia (eg, Raina et al, 1995). But location of microsporidian spores in the fat bodies of $A$ scotica adults provides no clue to the microsporidium's mechanism or mode of transmission.

Vertically transmitted microsporidian parasites of other arthropods have been shown to act as sex ratio distorters of their hosts (Dunn et al, 1995), biasing the sex ratio towards female hosts and theoretically enhancing the spread of the microsporidium in host populations (Hurst, 1993; Dunn et al, 1995). Other vertically transmitted cytoplasmic parasites are also thought or known to increase their transmission by biasing the sex ratio of their hosts towards 
females (Hurst, 1993). In this light, it is interesting to note a female biased sex ratio within A scotica at Törnbottens Stugby, though one which may be partly accounted for by inbreeding (Paxton and Tengö, 1996; Paxton et al, 1996).

Parasites have been hypothesized to provide an important selective force shaping the genetic structure of social groups (Sherman et al, 1988; Shykoff and SchmidHempel, 199la) and to impose a cost to group living (Keymer and Read, 1991). We did not collect data explicitly to examine the relationships between the number of $A$ scotica females sharing a communal nest, microsporidian parasitism and the sociogenetic organization of communal nests. Andrena scotica exhibits high relative intranest genetic variability (low nestmate relatedness, Paxton et al, 1996), a condition which would appear to mitigate the effects of parasitism (Shykoff and Schmid-Hempel, 1991a). However the high rate of infection of $A$ scotica from all nests at Törnbottens Stugby suggests that microsporidian parasitism may have little bearing on $A$ scotica's sociogenetic organization.

\section{ACKNOWLEDGMENTS}

We thank N Gyllenstrand for assistance in the field and laboratory, R Larsson for his generous help and discussion on the identity of microsporidia, and an anonymous referee for helpful comments on the manuscript. RJP gratefully acknowledges the support of the European Union (HCM-program), the Wenner-Gren foundation and the DFG and JT that of the Swedish NFR.

Résumé -_ Forte incidence de l'infection par une microsporidie non décrite (Microspora) chez l'abeille Andrena scotica (Hymenoptera, Andrenidae). Nous étudions l'abondance et la distribution des spores d'une espèce non décrite de Microspora au sein de son hôte, l'abeille monovoltine Andrena scotica, et les relations hôte-parasite. Les abeilles hôtes ont été récoltées lors de leur émergence en un lieu. TS, dans le sud-est de la Suède, disséquées et examinées au microscope à contraste de phase pour déceler la présence et la localisation des spores de microsporidies. Le tissu infecté a été examiné en microcopie électronique à transmission (TEM). Des abeilles hôtes ont été également récoltées à divers moments de leur vie adulte : pendant l' "hivernage» dans leurs cellules natales, à l'«émergence», «au champ» au cours de leur activité de reproduction et à leur mort dans une «cage» de vol. Pour chacun de ces stades un homogénat a été fait et le nombre de spores compté à l'aide d'un hémocytomètre. Des abeilles hôtes ont été récoltées à l'émergence et maintenues en cage de vol jusqu’à leur mort pour déterminer la relation entre la charge en spores et la longévité. On a également recherché les spores de la microsporidie dans des spécimens d'A scotica provenant d'autres sites et provenant d'autres espèces d'abeilles ( $y$ compris Nomada marshamella, l'abeille coucou d'A scotica à TS). La TEM laisse penser que le parasite est une espèce actuellement non décrite de Microspora (fig 1). La microsporidie est limitée au tissu adipeux (fig 2) et à l'hémolymphe d'A scotica. Il semble qu'elle épuise le tissu adipeux des individus fortement infectés. À TS, tous les nids hôtes renfermaient quelques abeilles émergentes qui étaient infestées (tableau I). Les femelles hôtes infestées ont émergé légèrement plus tôt que celles qui apparemment ne l'étaient pas, mais on n'a pas noté de différence de poids (tableau II). Le nombre de spores dans les homogénats d'A scotica du site TS (jusqu'à $118 \times 10^{6}$ par individu) suggère que les abeilles étaient toutes infectées (tableau III). Ces données suggèrent aussi que l'activité de reproduction des mâles n'est pas influencée par l'infection microsporidienne, alors que les femelles fortement infectées semblent avoir été moins susceptibles d'approvisionner un nid. Il n'y a pas de relation entre la longévité 
des hôtes mâles et femelles en cage de vol et la charge en spores (fig 3). La microsporidie semble donc avoir un effet négatif sur la fécondité de l'hôte femelle et n'influencer ni la fécondité de l'hôte mâle ni la longévité des deux sexes. Des spores de la microsporidie ont été décelées chez des individus d' $A$ scotica d'autres sites dans le sud est de la Suède mais pas chez d'autres espèces d'abeilles (tableau IV). La microsporidie serait donc largement répandue chez $A$ scotica mais serait hautement spécifique quant à son hôte.

Andrena scotica / infection / parasite / microsporidie / Microspora

\section{Zusammenfassung — Gehäuftes Auftreten von Infektionen bei der kommunal nisten- den Biene Andrena scotica (Hymenoptera,} Andrenidae) durch ein bisher nicht beschriebenes Microsporidium (Microspora). Wir beschreiben die Häufigkeit von Sporen einer bislang unbeschriebenen Art von Microspora und deren Verteilung zwischen seinen Wirten, der einjährigen, in Gemeinschaft nistenden Biene Andrena scotica, sowie die Beziehungen zwischen diesem Parasiten und seinem Wirt. Die Bienen wurden beim Schlupf im Freiland im südöstlichen Schweden gesammelt (TS). Die Tiere wurden präpariert und mit Phasenkontrastmikroskopie auf Befall und Ort des Befalls durch Mikrosporidiensporen hin untersucht. Befallenes Gewebe wurde mit Transmissionselektronenmikroskopie (TEM) weiter untersucht. Die Wirtsbienen wurden zu verschiedenen Zeiten ihres Erwachsenenlebens gesammelt: während des Überwinterns in ihren Brutzellen, beim Schlupf, während ihrer Reproduktion im Freien und nach ihrem Tod in einem Flugkäfig. Die Anzahl von Sporen in Homogenaten der Bienen wurden in einem Hämozytometer bestimmt. Um den Zusammenhang zwischen Sporengehalt und Lebensdauer bestimmen zu können, wurden einige Wirtstiere beim Schlupf gesammelt und bis zu ihrem Tod in Flugkäfigen gehalten. Weiterhin wurde Andrena scotica von anderen Freilandvorkommen, sowie weitere Bienenarten auf einen Befall hin untersucht (darunter auch Nomada marshamella, die Kukuksbiene von $A$ scotica, im Freiland TS). Nach den Ergebnissen der TEM - Untersuchung ist anzunehmen, daß es sich um eine bislang nicht beschriebene Art von Microspora handelt (Fig 1). Der Befall war auf das Fettgewebe (Fig 2) und die Hämolymphe von A scotica beschränkt, bei hochbefallenen Tieren wurde offensichtlich das Fettgewebe aufgezehrt. Alle Wirtsnester am Untersuchungsort TS enthielten einige befallene Tiere (Tabelle I). Befallene weibliche Wirtstiere schlüpften etwas eher als offensichtlich unbefallene Tiere, ihr Gewicht unterschied sich allerdings nicht (Tabelle II). Nach Sporenzählungen an den Homogenaten individueller A scotica vom Untersuchungsort TS wiesen alle Tiere von dort einen Befall auf, es wurden bis zu $118 \times 10^{6}$ Sporen pro Tier gefunden (Tabelle III). Die Daten legen nahe, daß die reproduktive Aktivität der männlichen Tiere durch den Befall nicht beeinträchtigt war, während stark befallene Weibchen weniger häufig ein Nest versorgen konnten. Die Lebensdauer in Flugkäfigen stand weder bei den Weibchen noch bei den Männchen mit dem Mikrosporidienbefall im Zusammenhang (Fig 3) Das Mikrosporidium hat damit einen negativen Einfluss auf die Fruchtbarkeit der weiblichen Wirte, keinen Einfluss auf die der männlichen Wirte, und keinerlei Einfluss auf die Lebensdauer beider Geschlechter. Die Microsporidiensporen wurden auch an anderen Sammelorten in Südostschweden gefunden, aber nicht in den anderen untersuchten Bienenarten (Tabelle IV). Dieses Ergebnis spricht dafür, daß dieses Mikrosporidium zwar weitverbreitet ist, dabei aber einen hohen Grad an Wirtsspezifität aufweist.

Andrena scotica / kommunale Bienen / Infektionen / Microspora / Mikrosporidium 


\section{REFERENCES}

Abacus Concepts (1995) STATVIEW 4.5. Abacus Concepts Inc, Berkeley, USA

Becnel J (1994) Life cycles and host-parasite relationships of Microsporidia in culicine mosquitoes. Folia Parasitol 41, 91-96

Blunck H (1954) Mikrosporidien bei Pieris brassicae L, ihren Parasiten und Hyperparasiten. Z Ang Entomol 36, 313-333

Briano JA, Patterson RS, Cordo HA (1995) Long-term studies of the black imported fire ant (Hymenoptera: Formicidae) infected with a microsporidium. Environ Entomol 24, 1328-1332

Briano JA, Patterson RS, Becnel JJ, Cordo HA (1996) The black imported fire ant, Solenopsis richteri, infected with Thelohania solenopsae: intracolonial prevalence of infection and evidence for transovarial transmission. I Invertebr Pathol 67, 178-179

Cantwell GE (1970) Standard methods for counting Nosema spores. Am Bee J 110, 222-223

Dunn AM, Hatcher MJ, Terry RS, Tofts C (1995) Evolutionary ecology of vertically transmitted parasites: transovarial transmission of a microsporidian sex ratio distorter in Gammarus duebeni. Parasitology 111,91-109

Eijnde J van den, Vette N (1993) Nosema infection in honeybees (Apis mellifera $\mathrm{L}$ ) and bumblebees (Bombus terrestris L). Proc Exper Appl Entomol Netherlands Entomol Soc 4, 205-208

Fisher RM, Pomeroy N (1989) Incipient colony manipulation, Nosema incidence and colony productivity of the bumble bee Bombus terrestris (Hymenoptera: Apidae). J Kansas Entomol Soc 62, 581-589

Fries I (1993) Nosema apis a parasite in the honcy bee colony. Bee World 74, 5-19

Fries I, Feng F, Silva A da, Slemenda SB, Pieniazek NJ (1996) Nosema ceranae $\mathrm{n}$ sp (Microsporidia, Nosematidae), morphological and molecular characterization of a microsporidian parasite of the Asian honey bee Apis cerana (Hymenoptera, Apidae). Eur J Protistol 32, 356-365

Hurst LD (1993) The incidence, mechanisms and evolution of cytoplasmic sex ratio distorters in animals. Biol Rev 68, 121-193

Keymer AE, Read AF (1991) Behavioural ecology: the impact of parasitism. In: Parasite Host Associations: Coexistence or Conflict (CA Toft, A Aeschlimann, L Bolis, eds), Oxford University Press, New York, NY, USA

Larsson R (1986) Ultrastructure, function, and classification of Microsporidia. Progress in Protistology 1, 325-390

Macfarlane RP, Lipa JJ, Liu HJ (1995) Bumble bee pathogens and internal enemies. Bee World 76 , 130-148
McIvor CA, Malone LA (1995) Nosema bombi, a microsporidian pathogen of the bumble bee Bombus terrestris (L). New Zealand J Zool 22, 25-31

Michener, CD (1974) The Social Behavior of the Bees. A Comparative Study. Belknap Press of Harvard University Press, Cambridge, MA, USA

Norusis MJ (1990) SPSS Advanced Statistics 4.0 guide. SPSS Inc, Chicago, IL, USA

Paxton RJ, Tengö J (1996) Intranidal mating, emergence, and sex ratio in a communal bee Andrena jacobi Perkins 1921 (Hymenoptera: Andrenidae). $J$ Insect Behav 9, 421-440

Paxton RJ, Thorén PA, Tengö J, Estoup A, Pamilo P (1996) Mating structure and nestmate relatedness in a communal bee, Andrena jacobi (Hymenoptera: Andrenidae), using microsatellites. Mol Ecol 5, 511-519

Paxton RJ, Hedström L, Tengö J (1997) Fly parasites and other associates of a communal bee, Andrena scotica (Hymenoptera: Apoidae), on Öland, SE Sweden. Entomol Tidskr 117, 165-178

Raina SK, Das S, Rai MM, Khurad AM (1995) Transovarial transmission of Nosema locustae (Microsporida: Nosematidae) in the migratory locust Locusta migratoria migratorioides. Parasitol Res 81, 38-44

Rust RW (1991) Size-weight relationships in Osmia lignaria propinqua Cresson (Hymenoptera: Megachilidae). I Kansas Entomol Soc 62, 174-178

Sherman PW, Seeley TD, Reeve HK (1988) Parasites, pathogens, and polyandry in social Hymenoptera. Am Nat 131, 602-610

Showers RE, Jones FA, Moeller FE (1967) Cross-inoculation of the bumble bee Bombus fervidus with the microsporidian Nosema apis from the honey bee. J Econ Entomol 60, 774-777

Shykoff JA, Schmid-Hempel P (1991a) Genetic relatedness and eusociality: parasite-mediated selection on the genetic composition of groups. Behav Ecol Sociobiol 28, 371-376

Shykoff JA, Schmidt-Hempel P (199lb) Incidence and effects of four parasites in natural populations of bumble bees in Switzerland. Apidologie 22, 117-125

Tengö J (1979) Odour-released behaviour in Andrena male bees (Apoidea, Hymenoptera). Zoon 7, 15 48

Wang DI, Moeller FE (1970) The division of labor and queen attendance behaviour of nosema-infected worker honey bees. J Econ Entomol 63, 1539-1541

Werren JH, Zhang W, Guo LR (1995) Evolution and phylogeny of Wolbachia: reproductive parasites of arthropods. Proc $R$ Soc Lond B 261, 55-71

Westrich P (1989) Die Wildbienen Baden Württem bergs. Verlag Eugen Ulmer, Stuttgart 